\title{
Large-scale variation in wave attenuation of oyster reef living shorelines and the influence of inundation duration
}

\author{
Rebecca L. Morris \\ Megan K. LaPeyre \\ Bret M. Webb \\ Donna M. Bilkovic \\ Virginia Institute of Marine Science \\ et al
}

Follow this and additional works at: https://scholarworks.wm.edu/vimsarticles

Part of the Natural Resources and Conservation Commons

\section{Recommended Citation}

Morris, Rebecca L.; LaPeyre, Megan K.; Webb, Bret M.; Bilkovic, Donna M.; and et al, Large-scale variation in wave attenuation of oyster reef living shorelines and the influence of inundation duration (2021). Ecological Applications.

doli: 10.1002/eap.2382

This Article is brought to you for free and open access by the Virginia Institute of Marine Science at W\&M ScholarWorks. It has been accepted for inclusion in VIMS Articles by an authorized administrator of W\&M ScholarWorks. For more information, please contact scholarworks@wm.edu. 
Rebecca L. Morris ${ }^{1}$, Megan K. La Peyre ${ }^{2}$, Bret M. Webb ${ }^{3}$, Danielle A. Marshall ${ }^{4}$, Donna M.

4 Bilkovic $^{5}$, Just Cebrian ${ }^{6}$, Giovanna McClenachan ${ }^{7,8}$, Kelly M. Kibler ${ }^{9}$, Linda J. Walters ${ }^{7}$, David

5 Bushek $^{10}$, Eric L. Sparks ${ }^{11,12}$, Nigel A. Temple ${ }^{11}$, Joshua Moody ${ }^{13}$, Kory Angstadt ${ }^{5}$, Joshua

6 Goff $^{14}$, Maura Boswell ${ }^{15}$, Paul Sacks ${ }^{7}$, and Stephen E. Swearer ${ }^{1}$

${ }^{1}$ National Centre for Coasts and Climate, School of BioSciences, The University of Melbourne,

9 VIC 3010, Australia; ${ }^{2}$ U.S. Geological Survey, Louisiana Cooperative Fish and Wildlife

Research Unit, School of Renewable Natural Resources, Louisiana State University Agricultural

11 Center, Baton Rouge, LA 70803, USA; ${ }^{3}$ Department of Civil, Coastal \& Environmental

12 Engineering, University of South Alabama, Mobile, AL 36688, USA; ${ }^{4}$ School of Renewable

13 Natural Resources, Louisiana State University Agricultural Center, Baton Rouge, LA 70803,

14 USA; ${ }^{5}$ Virginia Institute of Marine Science, William \& Mary, Gloucester Point, VA 23062,

USA; ${ }^{6}$ Northern Gulf Institute, Mississippi State University, Stennis Space Center, MS 39529,

16 USA; ${ }^{7}$ Department of Biology and National Center for Integrated Coastal Research, University

17 of Central Florida, Orlando, FL 32816, USA; ${ }^{8}$ Department of Biological Sciences, Nicholls State

18 University, Thibodaux, LA 70301, USA; ${ }^{9}$ Department of Civil, Environmental \& Construction

19 Engineering and National Center for Integrated Coastal Research, University of Central Florida,

20 Orlando, FL 32816, USA; ${ }^{10}$ Haskin Shellfish Research Laboratory, Rutgers University, Port

21 Norris, NJ 08349, USA; ${ }^{11}$ Coastal Research and Extension Center, Mississippi State University,

22 Biloxi, MS 39532, USA; ${ }^{12}$ Mississippi-Alabama Sea Grant Consortium, Ocean Springs, MS

23 39564, USA; ${ }^{13}$ Partnership for Delaware Estuary, Wilmington, DE 19801, USA; ${ }^{14}$ Dauphin 
24 Island Sea Lab, Dauphin Island, AL 36528, USA; ${ }^{15}$ Department of Civil and Environmental 25 Engineering, Old Dominion University, Norfolk, VA 23529, USA.

26

27 Corresponding Author:

28 Rebecca Morris, Email rebecca.morris@unimelb.edu.au, Tel. +61 423392882

29

30

31 Running headline: Oyster reefs and coastal defence

32

33

34

35

36

37

38

39

40

41

42

43

44 
One of the paramount goals of oyster reef living shorelines is to achieve sustained and adaptive

47 coastal protection, which requires meeting ecological (i.e., develop a self-sustaining oyster

48 population) and engineering (i.e., provide coastal defence) targets. In a large-scale comparison

49 along the Atlantic and Gulf coasts of the United States, the efficacy of various designs of oyster

50 reef living shorelines at providing wave attenuation was evaluated accounting for the ecological

51 limitations of oysters with regards to inundation duration. A critical threshold for intertidal oyster

52 reef establishment is $50 \%$ inundation duration. Living shorelines that spent less than half of the

53 time $(<50 \%)$ inundated were not considered suitable habitat for oysters, however, were effective

54 at wave attenuation (68\% reduction in wave height). Reefs that experienced $>50 \%$ inundation

55 were considered suitable habitat for oysters, but wave attenuation was similar to controls (no

56 reef; $\sim 5 \%$ reduction in wave height). Many of the oyster reef living shoreline approaches

57 therefore failed to optimize the ecological and engineering goals. In both inundation regimes,

58 wave transmission decreased with an increasing freeboard (difference between reef crest

59 elevation and water level), supporting its importance in the wave attenuation capacity of oyster

60 reef living shorelines. However, given that the reef crest elevation (and thus freeboard) should be

61 determined by the inundation duration requirements of oysters, research needs to be re-focused

62 on understanding the implications of other reef parameters (e.g. width) for optimising wave

63 attenuation. A broader understanding of the reef characteristics and seascape contexts that result

64 in effective coastal defence by oyster reefs is needed to inform appropriate design and

65 implementation of oyster-based living shorelines globally.

66 Keywords: coastal management; coastal erosion; nature-based coastal defence; shoreline

67 protection; wave transmission 
69 Oyster reefs are highly valued as a fishery resource and as biogenic habitat for a diverse suite of marine species (Grabowski et al. 2012, Cohen and Humphries 2017). Their ecological and socio-

71 economic worth has driven extensive oyster reef restoration, in response to widespread declines

72 in oyster populations (85\% functionally extinct; Beck et al. 2011). Recently, there has been

73 increased interest in constructing or restoring oyster reefs for living shoreline applications to

74 stem erosion (Piazza et al. 2005; Bilkovic et al. 2016). Living shorelines are engineered

75 structures primarily composed of natural materials that can be used as an alternative to other

76 "harder" engineered structures, such as seawalls and rock revetments, which are environmentally

77 (Bulleri and Chapman 2010) and economically (Hinkel et al. 2014) costly. Oyster reefs can alter

78 hydrodynamic conditions in estuarine systems through increasing bed friction (Wright et al.

79 1990, Whitman and Reidenbach 2012, Styles 2015, Kitsikoudis et al. 2020), facilitating wave

80 attenuation (Manis et al. 2015) and accreting sediment on the leeward side of the reef (Salvador

81 de Paiva et al. 2018, Chowdhury et al. 2019). This will become particularly relevant in the future

82 as increased risk of climate change-related erosion and flooding to burgeoning human

83 populations along the coast (Young et al. 2011, Neumann et al. 2015, Meucchi et al. 2020) will

84 result in an increased need for investment in coastal protection infrastructure, and the

85 development of adaptive and sustainable approaches to shoreline protection (Morris et al. 2020).

Traditional coastal defence structures (e.g., seawalls, breakwaters) have usually

87 undergone extensive numerical and physical modelling to identify the important design

88 parameters and their performance under various environmental conditions (e.g. wave heights,

89 water depths). Low crested breakwaters are constructed at or below the water level (i.e.,

90 submerged), and can inform wave transmission at oyster reef living shorelines. In low crested 
91 breakwaters, wave transmission is most sensitive to the depth of breakwater submergence, the

92 incident wave height, and the crest width (Seabrook and Hall, 1998; van der Meer et al. 2005).

93 Wave transmission increases with increased submergence, increased incident wave height, and

94 decreased crest width (Seabrook and Hall, 1998; van der Meer et al. 2005). Crest width becomes

95 particularly important as submergence increases, whereas freeboard (difference between reef

96 crest elevation and water level) has a larger effect when submergence is reduced (Seabrook and

97 Hall, 1998). Secondarily, the period of the incident wave, the breakwater armour dimensions (in

98 the case of a rubble mound structure), and the breakwater slope have small effects on wave

99 transmission (Seabrook and Hall 1998).

100

101 with the placement of reef substratum such as oyster shell, pre-cast concrete structures, or

102 crushed limestone (Hernandez et al. 2018, Morris et al. 2019a) for oyster colonisation. Physical

103 modelling of the reef substrate agrees with findings from low-crested breakwaters that the

104 freeboard, crest width and incident wave height are key parameters for wave transmission (Allen

105 and Webb 2011, Webb and Allen 2015, Coghlan et al. 2016). This pattern of wave attenuation as

106 a function of water depth in relation to the crest elevation has also been confirmed in field

107 studies (Chauvin 2018, MacDonald 2018, Wiberg et al. 2018, Chowdhury et al. 2019, Zhu et al.

108 2020, Spiering et al. in revision). While this research has clearly shown that a smaller

109 submergence results in greater wave attenuation by oyster reefs, these findings do not take into

110 account oyster habitat requirements, a necessary consideration for the appropriate application of

111 oyster reef-based living shorelines.

112 Unlike static structures, the vertical reef building capacity of oysters makes them a

113 candidate for creating dynamic structures (Mitchell and Bilkovic 2019). Oyster reefs exhibit a 
114 natural resilience and adaptive capacity to recover quickly from major storm events (Livingston 115 et al. 1999) and are capable of accreting at a rate necessary to maintain elevation in areas facing 116 sea-level rise (Rodriguez et al. 2014) or local subsidence (Casas et al. 2015). A key variable that 117 affects the recruitment, survival, and growth of oyster reefs is the duration of inundation (Table 118 1), which is a function of the absolute elevation of the reef and the tidal range. The lower 119 elevation threshold of intertidal oysters is commonly determined by increased biofouling, 120 predation, competition, or sedimentation in the subtidal (Fodrie et al. 2014, Solomon et al. 2014), 121 whereas the maximum elevation of oysters in the intertidal is driven by availability of filter 122 feeding time and exposure to extreme temperature stress. The optimum inundation duration, 123 therefore, is a trade-off among these limiting factors. The inundation duration has been 124 reasonably well-studied for the eastern oyster (Crassostrea virginica) in some locations along the 125 east coast of the United States (Table 1). This species is generally found at $60-80 \%$ inundation, 126 with lower and upper boundaries at 50\% and 95\% inundation, respectively (Fodrie et al. 2014; 127 Byers et al. 2015; Ridge et al. 2014, 2017; Solomon et al. 2014; Marshall and La Peyre, 2020; 128 Table 1). Thus, for intertidal oysters, constructing a reef base at an elevation that spends more 129 than $50 \%$ of the time inundated is critical for oyster establishment. Consequently, there is a 130 dichotomy between the reef elevation for optimal engineering design and habitat provisioning for 131 oysters.

As efforts to characterise wave attenuation by oyster reef living shorelines are growing, 133 the aim of this paper is to assess whether observed trends in oyster reef wave attenuation apply 134 across different environments and reef types using data across a large spatial scale. Further, we 135 consider wave transmission alongside the ecological limitations for oysters to characterize the 136 expected balance between effective wave attenuation and likelihood of reef persistence. Wave 
137 attenuation was measured at 15 oyster reef living shoreline-control pairs in five locations (New

138 Jersey/Delaware, Virginia, Florida, Alabama and Louisiana) along the Atlantic and Gulf coasts

139 of the United States. At each location we assessed the effects of oyster reef living shorelines

140 compared to controls (no reef) on wave attenuation relative to the inundation duration of the reef.

141 It was predicted that: (1) wave transmission would be greater at oyster reefs with an inundation

142 duration of $>50 \%$ compared with $<50 \%$; (2) for oyster reefs with an inundation duration of $>$

$14350 \%$, wave attenuation would increase with width; and (3) there would be a difference in wave

144 transmission between shell-based and concrete-based oyster reefs. Furthermore, at the Virginia

145 and Florida reefs, we compared the wave height attenuation of oyster reef living shorelines to

146 rock sills and natural unrestored oyster reefs, respectively.

147

148 Methods

149 Study locations

150 The fifteen oyster reef living shoreline (hereafter, “oyster reef”)-control pairs (Fig. 1) were

151 selected to cover the diversity of techniques commonly employed, which varied within and

152 among states in terms of age, materials, and size (Table 2; Appendix S1: Table S1). The wave

153 climate in the offshore waters at each location was observed at the NDBC (National Data Buoy

154 Center) stations (Appendix S1: Fig. S1), and the wind field was observed at the closest NOAA

155 (National Oceanic and Atmospheric Administration) climate station (Appendix S1: Fig. S1) over

156 a two-year period from 2017 - 2018 and during the study period at each location (one week).

157 Wind fetch distances were calculated for each site using fetchR (Seers 2018). 
Study sites at Nantuxent (NJ1; 39.2848, -75.2361) and Gandy’s Beach (NJ2; 39.2789, -

161

162

163

164

165

166

167

168

169

170

171

172

75.2430) were located on the western shore of New Jersey; the site at Mispillion (NJ3; 38.9477, 75.3149) was located on the eastern shore of Delaware, in Delaware Bay (Table 2). In 2016, nine shell bag oyster reefs were installed at Gandy's Beach on land owned by The Nature Conservancy, and a series of Oyster Castles ${ }^{\circledR}$ were installed at Nantuxent next to Money Island Marina (The Nature Conservancy 2017). These sites have high value, both economically (Money Island Marina was the off-load point for the NJ commercial oyster fleet) and environmentally (Gandy's Beach is a nesting site for horseshoe crabs and a feeding ground for the migrating red knot). Oyster Castles ${ }^{\circledR}$ were also installed at the mouth of the Mispillion River, immediately adjacent to the DuPont Nature Center (Moody et al. 2016), situated across the river from a large breakwater present on the bay-side. This site is a common feeding area for red knots during their spring/summer migration, is home to one of a few naturally occurring intertidal oyster reefs in Delaware, and the aim was to expand the natural oyster reef to stabilize eroding saltmarsh. The tides in Delaware Bay are semi-diurnal, and the mean tidal range is $1.7 \mathrm{~m}$ (NOAA station 8535055; Table 2). In the offshore waters, the predominant wave direction is from the east and south-east, with an average significant wave height of $1.05 \mathrm{~m}$ from this direction in the period $2017-2018$, and $0.83 \mathrm{~m}$ during the study period (Appendix 1: Fig. S2). The predominant wind direction is from the west, where the greatest wind speeds were recorded during the study period (Appendix 1: Fig. S3). This corresponded to the direction with the largest fetch distances at NJ1 and NJ2 (Appendix S1: Table S1). During the deployment at NJ3, wind speeds were low $\left(<4 \mathrm{~ms}^{-1}\right)$ from the east and south. 


\section{Virginia}

Diggs (VA3; 37.4473, -76.2605) was located in Chesapeake Bay and Laws (VA1; 36.8973, -76.2721) and Captain Sinclair (VA2; 37.3245, -76.4275) were located in two subestuaries of Chesapeake Bay, the Lafayette River and Mobjack Bay, respectively (Table 2). The oyster reefs were constructed in 2016 - 2017 as erosion control for private waterfront properties and were made of Ready Reef, Oyster Castles ${ }^{\circledR}$ and bagged shell for Diggs, Laws, and Captain Sinclair, respectively. At all of the sites, there was also a section of shoreline protected by a rock sill with saltmarsh.

The tides in Chesapeake Bay are semi-diurnal and the mean tidal range is $0.7 \mathrm{~m}$ (NOAA station 8637689; Table 2). In the offshore waters, the predominant wave direction is from the east and south-east, with an average significant wave height of $0.93 \mathrm{~m}$ from this direction in the period 2017 - 2018, and $0.68 \mathrm{~m}$ during the study period (Appendix 1: Fig. S2). A southerly wind was predominant during the study period (Appendix 1: Fig. S3), which corresponded to the direction of the highest fetch at VA1 and VA2 (Appendix S1: Table S1). Although, the strongest wind (above $8 \mathrm{~m} \mathrm{~s}^{-1}$ ) was recorded from the north during the study, the direction with the largest fetch at VA3 (Appendix S1: Fig. S3; Table S1).

\section{Florida}

Florida sites were located on the east coast of Central Florida in Mosquito Lagoon, which encompasses the northernmost section of the Indian River Lagoon system (Table 2). The tides are semi-diurnal and the mean tidal range is $0.3 \mathrm{~m}$ (NOAA station 8721222 ; Table 2). The Indian River Lagoon System is long (195 km), shallow (1-3 m) and narrow (2-4 km), making it extremely fetch-limited (Appendix S1: Table S1) and only persistent south-east or north-west 
205 winds tend to cause flooding and erosion (Colvin et al. 2018). During the study the predominant

206 winds were from the south and southwest (Appendix 1: Fig. S3). In the offshore waters, the

207 predominant wave direction is from the east and northeast, with an average significant wave

208 height of $1.18 \mathrm{~m}$ from this direction in the period $2017-2018$, and $0.48 \mathrm{~m}$ during the study

209 period (Appendix 1: Fig. S2).

210 The oyster reefs Mosquito (FL1; 25.9589, -80.8746), Hallmark (FL2; 28.9684, -80.8803)

211 and Pufferfish (FL3; 28.9699, -80.8818) were oyster reef restoration projects constructed in

212 2010, 2017 and 2016, respectively using the oyster mat method (oyster shells attached to

213 aquaculture grade mesh; www.restoreourshores.org). The oyster reefs were restored on the

214 historic footprint of degraded natural reefs, and at all sites there were natural unrestored oyster

215 reefs adjacent to the oyster reef living shoreline.

216

217 Alabama

Alabama study sites were located in Portersville Bay; Northeastern Point aux Pines (AL1;

$21930.3881,-88.2943$ ) was on the north-eastern portion of a peninsula in the bay (Sharma et al.

220 2016), while Coffee Island 1 and 2 (AL2, AL3; 30.3428, -88.2552) were on the eastern shoreline

221 of Coffee Island (or Isle aux Herbes) (Table 2). The Point aux Pines reef was constructed in 2009

222 comprising three $25 \mathrm{~m}$ units of loose shell. The Coffee Island reefs, constructed in 2010, were

223 made of experimental units of bagged shell, ReefBLK ${ }^{\mathrm{SM}}$ and Reef Ball ${ }^{\mathrm{TM}}$, the latter two were

224 used in this study (Heck et al. 2012).

225 The tides in Portersville Bay are diurnal and the mean tidal range is $0.4 \mathrm{~m}$ (NOAA station

$2268735180 ;$ Table 2). In the offshore waters, the predominant wave direction is from the south and

227 south-east, with an average significant wave height of $0.89 \mathrm{~m}$ from this direction in the period 
$2282017-2018$, and $0.57 \mathrm{~m}$ during the study period (Appendix 1: Fig. S2). The most persistent

229 winds during the study were from the east and south-east (Appendix 1: Fig. S3), which also

230 corresponded to the direction of greatest fetch at these sites (i.e., south and east; Appendix S1:

231 Table S1). The small percentage of wind events $>10 \mathrm{~m} \mathrm{~s}^{-1}$ from the south/east direction were not

232 captured in this study, which likely result in the greatest wave events at these sites.

Louisiana

The sites were in the Biloxi Marsh estuary in Eloi Bay (LA1, LA2; 29.7760, -89.4071) and Lake Athanasio (LA3; 29.7459, -88.4688) in southeastern Louisiana (Table 2). This location

237 has diurnal tides with a mean tidal range of $0.4 \mathrm{~m}$ (NOAA station 8761305; Table 2). In Eloi

238 Bay, the living shoreline was constructed by the Coastal Protection and Restoration Authority of

239 Louisiana (CPRA) in 2016 to reduce wave energy in order to minimize adjacent marsh erosion

240 and provide a platform for oysters to grow on. A coastal engineering analysis based on wave

241 attenuation and stability was used to determine the final living shoreline design, which

242 incorporated multiple bioengineered designs, including Wave Attenuation Devices (WAD ${ }^{\circledR}$ ) and

243 ShoreJAX ${ }^{\mathrm{TM}}$, which were used in this study (Carter et al. 2016). At Lake Athanasio an

244 Oysterbreak ${ }^{\mathrm{TM}}$ shoreline protection reef was built by The Nature Conservancy in 2011. Wave

245 data for the period $2017-2018$ were not available for these sites, however, modelling by CHE

246 (2014) showed that the annual average wave height at the CPRA reefs between 1980 - 2012 was

$247 \quad 0.43 \mathrm{~m}$ (Appendix 1: Fig. S2). Relatively low wind speeds $\left(<6 \mathrm{~ms}^{-1}\right)$ were recorded

248 predominantly from the northwest and west during the study. The largest fetch distances are

249 from the south and east at the sites in this location, which was the prevailing wind direction 250 during 2017 - 2018 (Appendix S1: Table S1, Fig. S2). 


\section{Data collection}

253 Wave loggers (RBR ${ }^{\circledR}$ solo D wave; hereafter RBRs) were deployed for 48 hours (36 hrs for NJ2,

254 NJ3 and FL2 due to tide times and distance to travel between sites) at each reef, rotated over 5

255 weeks in June - July 2018. At each site four RBRs were deployed at a control (no reef) and

256 oyster reef treatment; one each placed offshore and onshore of the control or reef area $(\sim 2-5 \mathrm{~m}$

257 from the on- and off- shore reef edge; Fig. 1b). The control was selected to be as close to the reef

258 as possible (site dependent; a minimum of $\sim 10 \mathrm{~m}$ ), yet outside the reef zone of wave influence,

259 maintaining similar shoreline characteristics (e.g. vegetation, substrate type), orientation and

260 fetch. The RBRs were attached with cable ties to a metal or PVC pole that was hammered into

261 the seabed and the transect length between the onshore and offshore RBRs at each treatment was

262 measured. The RBRs were programmed using the software Ruskin (v1.13.12; mode = wave;

263 frequency $=1 \mathrm{~Hz}$; duration $=1024$; burst rate $=1$ hour) to collect wave data (significant wave

264 height, $\mathrm{H}_{\mathrm{s}}$, in metres and associated period, $\mathrm{T}$, in seconds). The wave data collected is assumed to

265 be primarily wind-driven, however, boat wakes may also be important wave sources in some

266 locations (Garvis 2009) and could have contributed to the wave heights in this study.

267 At LA1 and LA2, five RBRs were deployed: two placed onshore and offshore of the

268 control and three placed around two replicate reefs (two onshore of each reef and one offshore of

269 the reefs). A different set-up was used due to the difficulty of returning to the sites over multiple

270 days to rotate the RBRs (5 RBRs were the maximum we had available). As the reefs were

271 aligned with a similar orientation along the shoreline, we assumed that the offshore wave energy

272 would be consistent between reefs. There was no significant difference between the wave heights 
273 recorded at the offshore RBR for the control and reef treatments $\left(\mathrm{t}_{(37)}=-1.1996, \mathrm{P}>0.05\right)$,

274 providing further support of this assumption.

275 Ten photo-quadrats $\left(0.09 \mathrm{~m}^{2}\right)$ were taken of each reef at New Jersey, Delaware, Virginia

276 and Florida and the percentage cover of oysters was calculated using 25 random points assigned

277 using the program CPCe4.1 (Kohler and Gill, 2006). The percentage cover of oysters could not

278 be quantified at Alabama or Louisiana as water levels were too high during the sampling period

279 and the water too turbid to take photo-quadrats. The size of the reef (length, width, height) and

280 distance from shoreline was either measured in the field during RBR deployment or determined

281 from aerial imagery using ArcGIS. All reefs were positioned parallel to the shore.

In Virginia and Florida, rock sills and natural oyster reefs were added as an additional

283 treatment to the experimental design, respectively. In Virginia, rock sills were present at all sites

284 adjacent to the oyster reef living shoreline, and two additional RBRs were positioned onshore

285 and offshore of the structure at the same time as the oyster reef and control treatments, as before.

286 Unfortunately, one RBR was lost in a storm during the last deployment in Virginia, which left

287 five for deployment in Florida. Therefore, in Florida one RBR was placed onshore of the natural 288 oyster reefs, and the offshore wave height was assumed to be the same as that for the oyster reef

289 living shoreline, as before. At all sites, the natural oyster reef was directly in line and adjacent to 290 the oyster reef living shoreline. There was, however, a significant difference in the wave heights 291 recorded between the offshore RBR for the control and oyster reef living shoreline treatments $292\left(\mathrm{t}_{(122)}=-3.9571, \mathrm{P}<0.001\right)$, although the mean $\pm \mathrm{SE}$ was similar for both treatments $(0.01 \pm$ $293 \quad 0.001 \mathrm{~m})$. 


\section{Wave analysis}

296

297

298

299

300

301

302

303

304

305

306

307

The absolute pressure values recorded by the RBRs were converted to gauge pressure using atmospheric pressure data obtained from the closest weather stations to each site (Appendix S1: Fig. S1; Morris et al. 2019b). Wave data were post-processed to account for shoaling and breaking, where appropriate, using the method detailed in Haynes (2018) and (Morris et al. 2019b). Water densities were calculated using the Thermodynamic Equation of Seawater - 2010 (TEOS-10; IOC et al. 2010), using the known salinity at each location and water temperatures obtained from World Sea Temperatures (www.seatemperature.org). The corrected pressure data were then converted to water depth using this calculated water density (Eq. 1),

$$
d=\frac{P}{\rho_{w} g} \quad \text { (Eq. 1) }
$$

where $d$ is the water depth, $P$ is the pressure, $\rho_{w}$ is the density of water, and $g$ is the acceleration due to gravity.

The water levels were linearly detrended to remove low-frequency signal, which provided an average water depth for each burst (of 1024 samples per hour, as above) and a zeroaverage input for Fast-Fourier-Transform. A pressure response factor, $K_{p}$, was determined for each frequency bin of the Fast-Fourier-Transform (Eq. 2; Kamphuis 2010),

$$
K_{p}=\frac{\cosh (k(d+z))}{\cosh (k d)}
$$

where $k$ is the wave number, $d$ is the water depth, and $z$ is the logger level from the surface. The wave energy density spectrum was then corrected for depth by dividing it by the pressure response factor squared. The output wave energy density spectrum was divided into sea (1 to $10 \mathrm{~s}$ period) and swell (10 to $20 \mathrm{~s}$ period) components (USACE 1984). Significant wave 
317 heights for each logger $\left(\mathrm{H}_{\mathrm{s}}\right.$; using the zeroth-moment wave height $)$ were determined from the 318 wave spectrum (Eq. 3; Moeller et al. 1996),

$$
H_{s}=4 \sqrt{E_{\text {total }} /\left(\rho_{w} g\right)}
$$

320 where $E_{\text {total }}$ is the total energy defined as the integral of the wave energy density spectrum. The 321 wave period corresponding to the significant wave height, $\mathrm{T}_{1 / 3}$, was approximated as $1.2 T_{m 01}$, 322 where $T_{m 01}$ is the zero-crossing period (Eq. 4; Goda 2010),

$$
\left.T_{m 01}=\sqrt{m_{0} / m_{2}} \quad \text { (Eq. } 4\right)
$$

324 where $m_{0}$ and $m_{2}$ are the zeroth and second moments of the wave energy density spectrum, 325 respectively. Linear wave theory was used to calculate wave length, celerity and group velocity, 326 based on wave conditions at the offshore logger and assuming wave period did not change as the 327 wave approached shore. Wave celerity at the onshore RBR within each treatment at a site was 328 estimated based on Hunt (1979). This was used to calculate the shoaling coefficient (Eq. 5; 329 Haynes 2018),

$$
K_{s}=\sqrt{C_{g_{-} o f f} / C_{g_{-} o n}}
$$

331 where $C_{g_{-} \text {off }}$ is the offshore RBR wave group celerity, and $C_{g_{-} \text {on }}$ is the onshore RBR wave 332 group celerity. Predicted onshore wave heights were generated to account for shoaling (Eq. 6) 333 and breaking (using the co-efficient of 0.78 multiplied by the depth at the onshore gauge; Haynes 334 2018),

$$
H_{S_{-} \text {pred }}=H_{S_{-} \text {off }} K_{S}
$$

336 where $\mathrm{H}_{\text {s_pred }}$ is the predicted wave height and $\mathrm{H}_{\mathrm{s}_{-} \text {off }}$ is the offshore wave height. The wave 337 transmission coefficient was defined as the ratio of measured to predicted wave height (Eq. 7; 338 Haynes 2018), where the predicted wave height was the limiting of the shoaling or breaking 339 wave height, 


$$
K_{t}=H_{S_{-} o n} / H_{S_{-} \text {pred }}
$$

341 where $\mathrm{H}_{\mathrm{s}_{-} \text {on }}$ is the recorded wave height at the onshore RBR. The wave transmission coefficient

342 accounts for potential changes in wave height due to shoaling and breaking, but not other

343 processes that could not be controlled for in this study (e.g., refraction and diffraction). All

344 processing was done in MATLAB (MathWorks 1996) and resulted in hourly data for water 345 depth, significant wave height at each RBR, wave period and the wave transmission coefficient 346 during the period the RBRs were underwater (i.e. only at high tide for most locations).

347 The freeboard $(\mathrm{m})$ was calculated as the reef height minus the water depth. The

348 inundation duration was calculated as the percentage of time the entire reef was submerged (i.e., 349 the freeboard had a negative value) during the study period. The inundation period during the 350 study was compared to longer-term data using water levels at nearby USGS gauges (NOAA tides 351 and currents for Alabama; Appendix S1: Fig. S1). The difference between the reef crest elevation 352 and water level relative to NAVD88 was used to calculate the percentage of time the crest of the 353 reef was inundated. The reefs were categorised into more or less than $50 \%$ inundated; this 354 threshold was chosen as the lower limit of inundation for $C$. virginica (Table 1). Regression 355 slopes between onshore measured and predicted significant wave heights were compared for 356 controls, and oyster reefs based on inundation duration, width and construction material. Further 357 the wave heights were compared at controls, oyster reefs and either rock sills or natural oyster 358 reefs, at Virginia and Florida respectively. The effect of location (fixed, 3 levels: New Jersey, 359 Virginia, Florida), inundation duration (fixed, percentage), and age (fixed, years) on the 360 percentage cover of oysters was tested using a linear mixed effects model, with site nested in 361 location included as a random factor on log transformed data. A likelihood ratio test comparing 
362 the model with and without site was used to obtain a p-value for this random effect. All analyses

363 were done in R 3.4.0 (R Core Team 2017).

\section{Results}

366 Significant wave heights recorded at the sites ranged from $0-0.35 \mathrm{~m}$ during the study period 367 (Fig. 2a). Average water depth between the gauge pairs ranged from $0.16-2.35 \mathrm{~m}$ (Fig. 2b), 368 after reef emersion time was truncated from each data set (i.e., low tide). The NJ2 site 369 experienced the greatest depth of inundation (freeboard $=-1.88 \mathrm{~m}$ ) due to a combination of the 370 low height of this reef and New Jersey experiencing the greatest tidal range (Table 2), with a 371 potential contribution of the greater wave heights recorded during the study period (Fig. 2a). The 372 LA1 and LA2 sites experienced the least inundation (freeboard $=0.86 \mathrm{~m}$ ), with the crests 373 exposed $100 \%$ of the time (Table 2). The average freeboard of all reefs is listed in Appendix 1: 374 Table S1.

376 while the other 12 reefs were inundated more than $50 \%$ of the time and considered to be within

377 the tolerable aerial exposure limits for C. virginica (Table 1). Two reefs were fully inundated

378 during the study (AL1, AL2; Table 1, Fig. 2b). The categorisation of the reefs based on the 379 measured study conditions aligned with that estimated from the USGS gauges during the study 380 and longer-term from 2017-2019 (Table 1). In general, the inundation durations measured during 381 the study were representative of the longer-term data (Table 1), but at VA3 the inundation 382 duration was $30-40 \%$ greater during the study compared to the long-term data (Table 1 ). This is 383 likely due to the storm event captured causing wind and/or wave set-up, which generated the 384 second highest wave heights in the study (after NJ2; Fig. 2a). Similarly, the inundation duration 
385 at FL3 was 20\% less, and at AL3, 40\% more during the study compared to the long-term data.

386 The reason for these differences is less clear but is likely due to the water level data from the

387 USGS gauges not being site specific, and therefore providing an estimation only.

388 There was little difference between the percent change in wave height between the

389 controls (5.9\%) and oyster reefs that experienced greater than 50\% inundation duration (4.5\%;

390 Fig. 3a, b). In contrast, a $68.4 \%$ decrease in wave height was observed at reefs that were

391 inundated for less than $50 \%$ of the time (Fig. 3b). Despite this, when the freeboard was the same

392 between reefs that had either greater or less than 50\% inundation duration, the wave attenuation

393 was also similar (Fig. 4). Wave transmission significantly decreased with increasing positive

394 freeboard and decreasing submergence for both inundation regimes (Fig. 4). Thus, the overall

395 result of a lower wave attenuation of reefs that have a greater inundation duration is driven by

396 these reefs experiencing less time at the optimal freeboard for wave attenuation (i.e., a reef crest

397 elevation that is either at or above the water level). Reefs that had an inundation duration of

398 greater than $50 \%$ were categorised based on the range of widths to determine if reefs of a greater

399 width had a lower wave transmission. Based on the range of reef widths observed in this study,

400 width had little effect on the wave transmission of these reefs (Fig. 3c). Whether the reefs were

401 made of shell or concrete also had less of an effect on wave transmission compared to reef height

402 (Fig. 3d).

403

On average, the rock sills were 2.5 times taller than the oyster reefs in Virginia and spent

$40435 \%$ or less time inundated during the study (Table 2). Rock sills reduced wave heights by $72 \%$

405 compared to a 5\% and 3\% reduction in wave height at oyster reefs and controls, respectively

406 (Fig. 5a). In Florida, the restored oyster reefs were a similar width and height as the natural

407 unrestored reefs, with the latter having a slightly taller profile at FL2 and FL3 (Table 2). The 
wave attenuation was greatest at the natural reefs ( $84 \%)$, followed closely by the restored oyster reefs $(75 \%)$, compared to the controls (35\%; Fig. $5 b)$. However, the percent of variance explained by the linear model was lower at the natural $(15 \%)$ and restored (31\%) oyster reefs. There was no significant effect of location $\left(\mathrm{F}_{3,44}=0.03, \mathrm{P}>0.05\right)$, inundation duration $\left(\mathrm{F}_{1,4}=0.23, \mathrm{P}>0.05\right)$, or age $\left(\mathrm{F}_{1,4}=0.01, \mathrm{P}>0.05\right)$ on the percentage cover of oysters. However, there was a significant difference in the oyster cover among sites $(\mathrm{P}<0.001$; Table 1$)$.

\section{Discussion}

To achieve the goal of a sustainable coastal defence structure, oyster reef living shorelines must be effective at both hazard risk reduction and habitat provisioning for oysters. Understanding the coastal protection afforded by reefs within the habitat limitations of oysters is therefore important for identifying the parametric ranges for which oyster reefs and coastal defence overlap. Oyster reefs where the crest was inundated less than $50 \%$ of the time were almost 14 times more effective at reducing the wave heights observed during this study than those that had an inundation duration of more than $50 \%$. The width of the reefs that had $>50 \%$ inundation ranged from $0.6-6.6 \mathrm{~m}$; these widths had little effect on the wave transmission of the reefs. Eight out of the nine study sites where oyster colonisation could be quantified experienced the optimal inundation regime. However, the percentage cover of oysters varied among these sites, with no effect of inundation duration, age, or location.

The duration and depth of inundation are determined by the intertidal elevation of the reef and the tidal amplitude of an area (Byers et al. 2015), as well as periodic events such as stormdriven wind or wave set-up. The duration and depth of inundation have an effect on wave attenuation and on oyster recruitment, survival, and growth. Previous research has shown that 
431 oyster reefs are very effective at attenuating waves when the reef crest height is at, or above, the 432 water level (Chauvin 2018, MacDonald 2018, Wiberg et al. 2018, Chowdhury et al. 2019, Zhu et 433 al. 2020, Spiering et al. in revision). This is because waves are strongly modified or break as they 434 cross the reef (Wiberg et al. 2018). As the water levels increase, a reduction in wave height is 435 instead caused by the interaction of oscillatory motion with the reef, the effect of which 436 decreases with increasing water depth (Wiberg et al. 2018). Here, our data support this finding, 437 showing that the negative relationship between wave transmission and reef submergence is 438 evident across the large biogeographic scale studied.

It has been noted previously that some of the reefs studied may only spend $10-25 \%$ of the

440 time at the optimal freeboard for wave attenuation (MacDonald 2018, Wiberg et al. 2018, Zhu et 441 al. 2020). When reefs become submerged, the wave attenuation can decrease to 0-20\% (Wiberg 442 et al. 2018; Fig. 4). However, this inundation duration is within the optimal range for oyster 443 population establishment (Table 1). Critically, $C$. virginica do not tend to colonise substratum 444 where the inundation duration is less than approximately 50\% (Ridge et al. 2015; Table 1). Reefs 445 with crests above this threshold will not be colonised by oysters, although if the reef base is 446 within the optimal range then oyster habitat may be provided lower on the structure, but this will 447 not result in an oyster reef that can build and maintain itself (i.e., wave attenuation is provided by 448 the artificial reef base not the growing oyster reef; Morris et al. 2019). Greater submergence 449 times enhance feeding, and therefore growth of oysters (Solomon et al. 2014), and reduce 450 desiccation stress. Too much immersion time, however, can negatively affect oysters due to 451 greater fouling or predation in the subtidal (Fodrie et al. 2014). Thus, there is an optimum 452 inundation duration that varies slightly along the geographical range, but seems to be within a 5$45340 \%$ range (Table 1). This translates to oyster reefs spending a greater percentage of time outside 
454 of the freeboards that maximize wave attenuation, and can explain the overall difference in wave 455 attenuation of reefs that experienced more or less than $50 \%$ inundation duration in this study.

The extent to which the inundation duration affects wave attenuation is also dependent on

457 the tidal amplitude. Where the tidal range is low, the variation in wave attenuation will be less

458 than in areas that have a greater tidal range. Although all of the sites here are considered

459 microtidal (defined as a tidal range of 0-2 $\mathrm{m}$ as per Davies 1964), they still experienced a range

460 of tidal amplitudes (Table 2), with the reefs in New Jersey having a greater depth of inundation

461 than the other sites. In contrast to its effect on wave attenuation, an increased depth of inundation

462 can have a positive effect on oyster growth and reef height due to a greater volume of water

463 delivery per unit of time and flow velocity that affects feeding and larval delivery (Byers et al.

464 2015).

For the reefs where the percent cover of oysters could be measured, inundation duration

466 varied between $68-97 \%$ for all but one reef (FL1; 38\%). This variation was similar to that found

467 across a 1,500 km region from North Carolina to Florida (52-84\%; Byers et al. 2015), where

468 there was no effect of inundation duration across latitude, and therefore oyster reef properties.

469 There was, however, significant variation in percent cover of oysters among sites in this study

470 that was not a factor of inundation duration. Other physical variables that commonly affect

471 oyster reef properties are salinity and temperature (Byers et al. 2015). Temperature linearly

472 declines with increasing latitute, but as there was no effect of location on oyster cover, it is

473 unlikely to be the cause of the site variability. Similarly, given that oysters are found in each of

474 the areas studied, the salinity was considered to be suitable. Another factor that affects the

475 recruitment of reef substratum is larval availability. The reefs in this study relied on natural

476 recruitment from the water column. If the reefs are recruitment-limited then they may never 
477 establish an oyster population; larval dispersal and connectivity are therefore important

478 considerations in the siting of reef substratum (Lipcius et al. 2008, Puckett et al. 2018). Further,

479 as coastal defences are inherently built in turbulent, wave exposed environments, an added

480 variable of the threshold of exposure for oyster reef establishment is critical in oyster reef living

481 shorelines (Whitman and Reidenbach, 2012). The benthic flow across the reef can be

482 manipulated to enhance larval recruitment by increasing topographic complexity that creates

483 interstitual spaces, which lower the shear stresses that can dislodge larvae (Whitman and

484 Reidenbach, 2012).

The comparison of rock sills to oyster reefs further supports the importance of crest

486 height for wave attenuation in narrow structures. Rock sills showed a similar magnitude of wave

487 height reduction as the oyster reefs that were exposed for more than $50 \%$ of the time, which

488 again was much greater than the oyster reefs in Virginia that all had $<50 \%$ exposure. When

489 oyster reef living shorelines were compared to natural reefs in Florida, the wave attenuation was

490 similar between the two treatments ( $75 \%$ and $84 \%$, respectively), and double that of the control

491 (35\%). This is likely due to the similarity in size (height and width) of the restored and natural

492 reefs, as the restored reefs were deployed onto the historic footprint of natural degraded reefs.

493 However, the natural reefs had a very low percent cover of live oyster compared to the restored

494 reefs (except FL1). Live oysters increase bed roughness and therefore drag, which can lead to

495 better flow energy attenuation (Kitsikoudis et al. 2020). In contrast, degraded reefs consist of

496 loose disarticulated shells that can be moved around with wave events. Therefore, even though

497 the wave attenuation observed was similar between restored and natural degraded reefs here, it is

498 unclear how this may evolve through time, as degraded reefs could eventually disintegrate if not

499 colonised by oysters (Kitsikoudis et al. 2020). The pattern of wave attenuation across treatments 
500 in Florida, when considered alone, was very different to the overall patterns observed, as greater

501 attenuation was recorded at both the control and oyster reefs, but it was also more variable. This

502 is likely due to Florida experiencing only very small wave heights for the duration of the

503 deployment. Smaller, high frequency waves (e.g., $1 \mathrm{~s}$ period) may have been under-sampled with

504 the $1 \mathrm{~Hz}$ frequency used to compare treatments in this study, which potentially resulted in the

505 reporting of smaller wave heights than were present. However, similar maximum wave heights

506 have been recorded at other sites in Mosquito Lagoon, Florida, using a $32 \mathrm{~Hz}$ sampling

507 frequency (Kibler et al. 2019), thus our results are just as likely to be due to the calm weather

508 during deployments and the fact that these sites are very sheltered under normal conditions.

509 At the other locations, there was a range in wave heights observed and these were

510 comparable to those in previous studies in New Jersey (average $0.03-0.11 \mathrm{~m}$, maximum 0.15 -

$5110.55 \mathrm{~m}$; MacDonald 2018), Virginia (average $0.03-0.10 \mathrm{~m}$, maximum $0.30-0.50 \mathrm{~m}$; Wiberg et

512 al. 2018) and Louisiana (average $0.10 \mathrm{~m}$, maximum $0.45 \mathrm{~m}$; Chauvin 2018). Nevertheless, these

513 wave heights were generally more representative of calm to average conditions due to the trade-

514 off between the large-scale of the study and wave sensor deployment duration (36 - 48 hours),

515 which limited the range of wave conditions that could be observed. The size of the waves

516 (Wiberg et al. 2018, Chowdhury et al. 2019), as well as whether they are swell- or wind-

517 dominated (Zhu et al. 2020) or accompanied by storm tides, impacts the efficacy of oyster reefs

518 at wave attenuation. Previous studies of oyster reefs have shown that for the equivalent water

519 depth, wave attenuation increases with wave height (Wiberg et al. 2018, Chowdhury et al. 2019).

520 This may explain why fringing oyster reefs have been found to have a greater impact on

521 shoreline retreat at higher exposure locations (La Peyre et al. 2015). Hence, there is the potential

522 that with larger wave heights the wave transmission values observed in this study could decrease 
523 at oyster reef living shorelines. This highlights the need to examine multiple reefs experiencing

524 diverse conditions to get a complete understanding of how they work.

525 It is also important to consider the type of shoreline being protected, as habitat type can

526 influence susceptibility to erosion from different weather events. For example, saltmarsh was the

527 predominant shoreline type in our study. Leonardi et al. (2016) demonstrated that marsh-edge

528 erosion was caused by moderate, but high frequency ( $2.5 \pm 0.5$ per month $)$ storms. Larger

529 storms, in contrast, are often accompanied by storm surge, which dissipates over the marsh bed

530 rather than impacting the marsh edge. Previous research on oyster reef living shorelines has

531 shown significant variability in erosion control of saltmarsh among sites (Meyer et al. 1997,

532 Piazza et al. 2005, Stricklin et al. 2010, Scyphers et al. 2011, La Peyre et al. 2013, Moody et al.

5332013 , La Peyre et al. 2014, 2015). Oyster reefs are likely to have the greatest effect on the

534 reduction of saltmarsh erosion when the elevation of the marsh platform coincides with the water

535 depths that maximize wave attenuation (i.e., when reef submergence is low; Wiberg et al. 2018).

536 As currently designed, reefs that are within the habitat requirements for oysters are likely to have

537 little effect on higher-elevation shorelines dominated by saltmarshes. How this process translates

538 to protection by oyster reefs for other shoreline habitat types is not well known.

539 Natural oyster reefs were once vast, with historical imagery suggesting reefs kilometres

540 long fringed the shorelines in the 1800s in Chesapeake Bay, Virginia (Woods et al. 2005). A

541 recent study in Mosquito Lagoon, Florida, found that small-scale restored oyster reefs (as studied

542 here) had a cumulative positive impact on erosion rates that may not be observed at a single site

543 (McClenachan et al. 2020). The variability in effectiveness of oyster reefs at providing erosion

544 control may be the result of a mismatch in the scale of the construction of living shorelines and

545 that required for delivery of the coastal defence service. For example, McClenachan et al. (2020) 
546 demonstrated that the combined 89 smaller oyster reef projects had a landscape scale effect

547 within this ecosystem. At an individual scale, the reefs we studied were narrow structures. The

548 range of widths observed had little effect on the wave attenuation of the reefs that were at the

549 appropriate elevation for oysters. However, physical modelling of submerged rubble-mound

550 breakwaters (Seabrook and Hall, 1998) and bagged oyster shell reefs (Allen and Webb, 2011)

551 showed that wider structures of the same elevation can further decrease wave transmission by

$552 \quad 20-40 \%$. Field studies have shown width to be important for wave attenuation in saltmarshes

553 (Shepard et al. 2011) and coral reefs (Ferrario et al. 2014), however, this factor has not been

554 examined for oyster reefs. This is likely due to most of our knowledge on the wave transmission

555 of oyster reefs being generated from studies on living shorelines, with a paucity of information

556 available on natural reefs (Narayan et al. 2016). For living shorelines to be used as a tool for

557 restoration and risk reduction, it is imperative that we optimize the design to maximize both

558 ecological and engineering outcomes.

559

560 Conclusions

561 In the face of a changing climate, there is an increasing interest in living shorelines as an

562 adaptive and sustainable coastal defence strategy. For living shorelines to be successful, they

563 need to establish a self-sustaining population of the target species and have the ability to provide

564 coastal protection under the conditions that cause erosion and/or flooding. This large-scale study

565 across multiple states provides a broader perspective on the diversity of oyster reef living

566 shoreline approaches. We showed that many of the living shoreline approaches using oysters

567 failed to optimize the ecological and engineering goals. To date, studies have focused on

568 understanding the wave attenuation of oyster reefs without integrating consideration for the 
569 ecological limitations of oysters. This has resulted in a focus on how the crest of the reef

570 influences wave transmission. However, given that this design parameter needs to stay within the

571 optimal inundation duration for oysters, efforts should be refocused to understand the effects of

572 other design parameters, such as reef width, on maximising wave attenuation over a greater

573 inundation range. This approach should apply generally to the design and implementation of

574 living shorelines, where the engineering parameters are calculated to account for the ecological

575 limitations of a species in order to achieve both goals. Identifying the circumstances under which

576 living shorelines can be designed to achieve these goals is also important to determine the

577 thresholds for their use successfully. Our results suggest that the low-crested, narrow oyster reefs

578 that are commonly built are, on average, not effective at wave attenuation. Their ability to

579 provide erosion control, however, will also depend on the elevation of the shoreline and the

580 conditions that contribute to local erosion. This combination of factors has likely contributed to

581 the large variation in erosion control by oyster reef living shorelines reported in the literature. A

582 broader understanding of the reef characteristics and seascape contexts that result in effective

583 coastal defence by oyster reefs is needed to inform the design of future living shoreline projects.

584 This continued research effort will ensure that oyster reef living shorelines are successful in

585 achieving both their ecological and engineering goals.

586

587 Acknowledgements

588 We thank T. Graham for his advice on data processing and J. Shinn for her assistance with the

589 New Jersey sites. R.L.M. was supported by an Early Career Researcher Global Mobility Grant

590 from The University of Melbourne. The National Centre for Coasts and Climate is funded

591 through the Earth Systems and Climate Change Hub by the Australian Government's National 
592 Environmental Science Program. This paper is Contribution No. 3990 of the Virginia Institute of 593 Marine Science, William \& Mary. Any use of trade, firm, or product names is for descriptive 594 purposes only and does not imply endorsement by the U.S. Government.

595

596

597 598

600

601

602

603

604

605

606

607

608

609

610

611

612

613

614

615

\section{References}

Allen, R. J., and B. M. Webb. 2011. Determination of wave transmission coefficients for oyster shell bag breakwaters. Coastal Engineering Practice:684-697.

Beck, M. W., R. D. Brumbaugh, L. Airoldi, A. Carranza, L. D. Coen, C. Crawford, O. Defeo, G. J. Edgar, B. Hancock, M. C. Kay, H. S. Lenihan, M. W. Luckenbach, C. L. Toropova, G. F. Zhang, and X. M. Guo. 2011. Oyster reefs at risk and recommendations for conservation, restoration, and management. Bioscience 61:107-116.

Bilkovic, D. M., M. Mitchell, P. Mason, and K. Duhring. 2016. The role of living shorelines as estuarine habitat conservation strategies. Coastal Management 44:161-174.

Bulleri, F., and M. G. Chapman. 2010. The introduction of coastal infrastructure as a driver of change in marine environments. Journal of Applied Ecology 47:26-35.

Byers, J. E., J. H. Grabowski, M. F. Piehler, A. R. Hughes, H. W. Weiskel, J. C. Malek, and D. L. Kimbro. 2015. Geographic variation in intertidal oyster reef properties and the influence of tidal prism. Limnology and Oceanography 60:1051-1063.

Carter, J., C. Connor, J. Todd, A. Agarwal, and H. Bermudez. 2016. Living shoreline demonstration project, prepared for Louisiana Coastal Protection and Restoration Authority. Coast and Harbor Engineering, a division of Mott MacDonald, New Orleans.

Casas, S. M., J. La Peyre, and M. K. La Peyre. 2015. Restoration of oyster reefs in an estuarine lake: population dynamics and shell accretion. Marine Ecology Progress Series 524:171184. 
Chauvin, J. M. 2018. Wave attenuation by constructed oyster reef breakwaters. Louisiana State University, Louisiana, US.

Chowdhury, M. S. N., B. Walles, S. M. Sharifuzzaman, M. Shahadat Hossain, T. Ysebaert, and A. C. Smaal. 2019. Oyster breakwater reefs promote adjacent mudflat stability and salt marsh growth in a monsoon dominated subtropical coast. Scientific Reports 9:8549.

Coast and Harbor Engineering, CHE. 2014. Living Shoreline Demonstration Project, Coastal Engineering and Alternatives Analysis. Baton Rouge, LA. October 9, 2014.

Coen, L. D., and A. T. Humphries. 2017. Chapter 19. Oyster-generated marine habitats: their services, enhancement and monitoring. In: S. Stuart and S. Murphy (eds) Routledge Handbook of Ecological and Environmental Restoration, Routledge: New York, 274294.Colvin, J., S. Lazarus, M. Splitt, R. Weaver, and P. Taeb. 2018. Wind driven setup in east central Florida's Indian River Lagoon: forcings and parameterizations. Estuarine, Coastal and Shelf Science 213:40-48.

Coghlan, I. R., Howe, D. and W. C. Glamore. 2016. Preliminary testing of oyster shell filled bags. WRL Technical Report 2015/20, January.

Davies, J. L. 1964. A morphogenic approach to world shorelines. Zeitschrift Fur Geomorphologie 8:27-42.

Ferrario, F., M. W. Beck, C. D. Storlazzi, F. Micheli, C. C. Shepard, and L. Airoldi. 2014. The effectiveness of coral reefs for coastal hazard risk reduction and adaptation. Nature Communications 5:3794.

Fodrie, F. J., A. B. Rodriguez, C. J. Baillie, M. C. Brodeur, S. E. Coleman, R. K. Gittman, D. A. Keller, M. D. Kenworthy, A. K. Poray, J. T. Ridge, E. J. Theuerkauf, and N. L. Lindquist. 2014. Classic paradigms in a novel environment: inserting food web and productivity 
lessons from rocky shores and saltmarshes into biogenic reef restoration. Journal of Applied Ecology 51:1314-1325.

Garvis, S. K. 2009. Quantifying the impacts of oyster reef restoration on oyster coverage, wave dissipation and seagrass recruitment in Mosquito Lagoon, Florida. University of Central Florida, Florida, United States.

Goda, Y. 2010. Random seas and design of maritime structures. World Scientific Publishing Co. Pte. Ltd., Singapore.

Grabowski, J. H., R. D. Brumbaugh, R. F. Conrad, A. G. Keeler, J. J. Opaluch, C. H. Peterson, M. F. Piehler, S. P. Powers, and A. R. Smyth. 2012. Economic valuation of ecosystem services provided by oyster reefs. Bioscience 62:900-909.

Haynes, K. M. 2018. Field measurements of boat wake attenuation in coastal salt marshes. University of South Alabama.

Heck, K., J. Cebrian, S. Powers, R. Gericke, C. Pabody, and J. Goff. 2012. Final Monitoring Report to the Nature Conservancy: Coastal Alabama Economic Recovery and Ecological Restoration Project: Creating jobs to protect shorelines, restore oyster reefs and enhance fisheries productions, Dauphin Island Sea Lab and University of South Alabama, Dauphin Island.

Hernandez, A. B., R. D. Brumbaugh, P. Frederick, R. Grizzle, M. W. Luckenbach, C. H. Peterson, and C. Angelini. 2018. Restoring the eastern oyster: how much progress has been made in 53 years? Frontiers in Ecology and the Environment 16:1-9.

Hinkel, J., D. Lincke, A. T. Vafeidis, M. Perrette, R. J. Nicholls, R. S. J. Tol, B. Marzeion, X. Fettweis, C. Ionescu, and A. Levermann. 2014. Coastal flood damage and adaptation 

$111: 3292-3297$.

663 664 665 666 667 668 669

670 671 672 673 674 675 676 677 678 679 680 681
Hunt, J. N. 1979. Direct solution of wave dispersion equation. Journal of Waterway, Port, Coastal, and Ocean Engineering 4:457-459.

IOC, SCOR, and IAPSO. 2010. The international thermodynamic equation of seawater - 2010: calculation and use of thermodynamic properties. Intergovernmental Oceanographic Commission, Manuals and Guides No. 56, UNESCO.

Kamphuis, J. W. 2010. Introduction to coastal engineering and management, Advanced series on ocean engineering. World Scientific, Singapore.

Kibler, K. M., V. Kitsikoudis, M. Donnelly, D. W. Spiering, and L. Walters. 2019. Flowvegetation interaction in a living shoreline restoration and potential effect to mangrove recruitment. Sustainability 11:3215.

Kitskoudis, V., K. M. Kibler, and L. J. Walters. 2020. In-situ measurements of turbulent flow over intertidal natural and degraded oyster reefs in an estuarine lagoon. Ecological Engineering 143:1056882.

Kohler, K. E., and S. M. Gill. 2006. Coral Point Count with Excel extensions (CPCe): A Visual Basic program for the determination of coral and substrate coverage using random point count methodology. Computers and Geosciences 32:1259-1269.

La Peyre, M. K., A. T. Humphries, S. M. Casas, and J. F. La Peyre. 2014. Temporal variation in development of ecosystem services from oyster reef restoration. Ecological Engineering $63: 34-44$. 
La Peyre, M. K., L. Schwarting, and S. Miller. 2013. Preliminary assessment of bioengineered fringing shoreline reefs in Grand Isle and Breton Sound, Louisiana. Report 2013-1040, Reston, VA.

La Peyre, M. K., K. Serra, T. A. Joyner, and A. Humphries. 2015. Assessing shoreline exposure and oyster habitat suitability maximizes potential success for sustainable shoreline protection using restored oyster reefs. PeerJ, 3, e1317.

Leonardi, N., N. K. Ganju, and S. Fagherazzi. 2016. A linear relationship between wave power and erosion determines salt-marsh resilience to violent storms and hurricanes. Proceedings of the National Academy of Sciences 113:64.

Lipcius, R. N., D. B. Eggleston, S. J. Schreiber, R. D. Seitz, J. Shen, M. Sisson, W. T. Stockhausen, and H. V. Wang. 2008. Importance of metapopulation connectivity to restocking and restoration of marine species. Reviews in Fisheries Science 16:101-110.

Livingston, R. J., R. L. Howell, X. F. Niu, F. G. Lewis, and G. C. Woodsum. 1999. Recovery of oyster reefs (Crassostrea virginica) in a gulf estuary following disturbance by two hurricanes. Bulletin of Marine Science 64:465-483.

MacDonald, M. 2018. Wave monitoring and sedimentation analysis at four oyster castle breakwaters at Gandy's Beach, NJ. For: The Nature Conservancy. New Jersey, US.

Manis, J. E., S. K. Garvis, S. M. Jachec, and L. J. Walters. 2015. Wave attenuation experiments over living shorelines over time: a wave tank study to assess recreational boating pressures. Journal of Coastal Conservation 19:1-11.

Marshall, D. A. and La Peyre, M. K. 2020. Effects of inundation duration on southeastern Louisiana oyster reefs. Experimental Results. 
MathWorks, I. 1996. MATLAB : the language of technical computing : computation, visualization, programming : installation guide for UNIX version 5. Natwick: Math Works Inc., 1996.

McClenachan, G. M., M. J. Donnelly, M. N. Schaffer, P. E. Sacks, and L. J. Walters. 2020. Does size matter?: Quantifying the cumulative impact of small-scale living shoreline and oyster reef restoration projects on shoreline erosion. Restoration Ecology https://doi.org/10.1111/rec.13235.

Meucci, A., I. R. Young, M. Hemer, E. Kirezci, and R. Ranasinghe. 2020. Projected 21st century changes in extreme wind-wave events. Science Advances 6:eaaz7295.

Meyer, D. L., E. C. Townsend, and G. W. Thayer. 1997. Stabilization and erosion control value of oyster cultch for intertidal marsh. Restoration Ecology 5:93-99.

Mitchell, M., and D. M. Bilkovic. 2019. Embracing dynamic design for climate-resilient living shorelines. Journal of Applied Ecology Doi: 10.1111/1365-2664.13371.

Moeller, I., T. Spencert, and J. R. French. 1996. Wind wave attenuation over saltmarsh surfaces: preliminary results from Norfolk, England. Journal of Coastal Research 12:1009-1016.

Moody, J., D. Kreeger, S. Bouboulis, S. Roberts, and A. Padeletti. 2016. Design, implementation, and evaluation of three living shoreline treatments at the DuPont Nature Center, Mispillion River, Milford, DE., Partnership for the Delaware Estuary, Wilmington.

Moody, R. M., J. Cebrian, S. M. Kerner, K. L. Heck, S. P. Powers, and C. Ferraro. 2013. Effects of shoreline erosion on salt-marsh floral zonation. Marine Ecology Progress Series 488:145-155. 
Morris, R. L., D. M. Bilkovic, M. K. Boswell, D. Bushek, J. Cebrian, J. Goff, K. M. Kibler, M. K. La Peyre, G. McClenachan, J. Moody, P. Sacks, J. P. Shinn, E. L. Sparks, N. A. Temple, L. J. Walters, B. M. Webb, and S. E. Swearer. 2019a. The application of oyster reefs in shoreline protection: are we over-engineering for an ecosystem engineer? Journal of Applied Ecology Doi: 10.1111/1365-2664.13390.

Morris, R. L., A. Boxshall, and S. E. Swearer. 2020. Climate-resilient coasts require diverse defence solutions. Nature Climate Change 10:485-487.

Morris, R. L., T. D. J. Graham, J. Kelvin, M. Ghisalberti, and S. E. Swearer. 2019b. Kelp beds as coastal protection: wave attenuation of Ecklonia radiata in a shallow coastal bay Annals of Botany Doi: 10.1093/aob/mcz127.

Narayan, S., M. W. Beck, B. G. Reguero, I. J. Losada, B. van Wesenbeeck, N. Pontee, J. N. Sanchirico, J. C. Ingram, G. M. Lange, and K. A. Burks-Copes. 2016. The effectiveness. costs and coastal protection benefits of natural and nature-based defences. PLoS ONE 11.

Neumann, B., A. T. Vafeidis, J. Zimmermann, and R. J. Nicholls. 2015. Future coastal population growth and exposure to sea-level rise and coastal flooding - A global assessment. PLoS ONE 10:e0118571.

Piazza, B. P., P. D. Banks, and M. K. La Peyre. 2005. The potential for created oyster shell reefs as a sustainable shoreline protection strategy in Louisiana. Restoration Ecology 13:499506.

Puckett, B. J., S. J. Theuerkauf, D. B. Eggleston, R. Guajardo, C. Hardy, J. Gao, and R. A. Luettich. 2018. Integrating Larval Dispersal, Permitting, and Logistical Factors Within a Validated Habitat Suitability Index for Oyster Restoration. Frontiers in Marine Science 5:75. 
R Core Team. 2017. R: A Language and Environment for Statistical Computing. R Foundation for Statistical Computing, Vienna Austria. Available online at : http://www.R-project.org

Ridge, J. T., A. B. Rodriguez, F. J. Fodrie, N. L. Lindquist, M. C. Brodeur, S. E. Coleman, J. H. Grabowski, and E. J. Theuerkauf. 2015. Maximizing oyster-reef growth supports green infrastructure with accelerating sea-level rise. Scientific Reports 5:14785.

Ridge, J. T., A. B. Rodriguez, and F. J. Fodrie. 2017. Salt Marsh and Fringing Oyster Reef Transgression in a Shallow Temperate Estuary: Implications for Restoration, Conservation and Blue Carbon. Estuaries and Coasts 40:1013-1027.

Rodriguez, A. B., F. J. Fodrie, J. T. Ridge, N. L. Lindquist, E. J. Theuerkauf, S. E. Coleman, J. H. Grabowski, M. C. Brodeur, R. K. Gittman, D. A. Keller, and M. D. Kenworthy. 2014. Oyster reefs can outpace sea-level rise. Nature Climate Change 4:493-497.

Salvador de Paiva, J. N., B. Walles, T. Ysebaert, and T. J. Bouma. 2018. Understanding the conditionality of ecosystem services: the effect of tidal flat morphology and oyster reef characteristics on sediment stabilization by oyster reefs. Ecological Engineering 112:8995.

Scyphers, S. B., S. P. Powers, K. L. Heck, and D. Byron. 2011. Oyster reefs as natural breakwaters mitigate shoreline loss and facilitate fisheries. PLoS ONE 6:e22396.

Seabrook, S. and K. Hall. 1998. Wave transmission at submerged rubblemound breakwaters. Coastal Engineering Proceedings 1 (26).

Seers, B. 2018. fetchR: calculate wind fetch.

Sharma, S., J. Goff, R. M. Moody, A. McDonald, D. Byron, K. L. Heck, Jr., S. P. Powers, C. Ferraro, and J. Cebrian. 2016. Effects of shoreline dynamics on saltmarsh vegetation. PLoS ONE 11:e0159814. 
772 Shepard, C. C., C. M. Crain, and M. W. Beck. 2011. The protective role of coastal marshes: a

773

774 775

776

777

778

779

780

781

782

783

784

785

786

787

788

789

790

791

792

793

794 systematic review and meta-analysis. PLoS ONE 6:e27374.

Solomon, J. A., M. J. Donnelly, and L. J. Walterst. 2014. Effects of sea level rise on the intertidal oyster Crassostrea Virginica by field experiments. Journal of Coastal Research 68:57-64.

Spiering, D. W., K. M. Kibler, V. Kitskoudis, M. Donnelly, and L. J. Walters. in revision.

Detecting hydrodynamic changes after living shoreline restoration and through an extreme event using a Before-After-Control-Impact experiment. Estuaries and Coasts.

Stricklin, A. G., M. S. Peterson, J. D. Lopez, C. A. May, and C. F. Mohrman. 2010. Do small, patchy, constructed intertidal oyster reefs reduce salt marsh erosion as well as natural reefs? Gulf and Caribbean Research 22:21-27.

Styles, R. 2015. Flow and turbulence over an oyster reef. Journal of Coastal Research 31:978985.

The Nature Conservancy. 2017. Gandy’s Beach shoreline protection project - final performance report. The Nature Conservancy, Delmont.

USACE. 1984. Shore protection manual. U.S. Army Corps of Engineers, Mississippi.

van der Meer, J. W., R. Briganti, B. Zanuttigh, and B. Wang. 2005. Wave transmission and reflection at low-crested structures: design formulae, oblique wave attack and spectral change. Coastal Engineering 52:915-929.

Webb, B. M., and R. J. Allen. 2015. Wave transmission through artificial reef breakwaters. Coastal Structures and Solutions to Coastal Disasters. ASCE.

Whitman, E. R., and M. A. Reidenbach. 2012. Benthic flow environments affect recruitment of Crassostrea virginica larvae to an intertidal oyster reef. Marine Ecology Progress Series 463:177-191. 
795 Wiberg, P. L., S. R. Taube, A. E. Ferguson, M. R. Kremer, and M. A. Reidenbach. 2018. Wave 796 attenuation by oyster reefs in shallow coastal bays. Estuaries and Coasts 42:331-347.

797 Woods, H., W. J. Hargis, C. H. Hershner, and P. A. M. Mason. 2005. Disappearance of the 798 799 800 801 natural emergent 3-dimensional oyster reef system of the James River, Virginia 18711948. Journal of Shellfish Research 24:139-142.

Wright, L. D., R. A. Gammisch, and R. J. Byrne. 1990. Hydraulic roughness and mobility of three oyster-bed artificial substrate materials. Journal of Coastal Research 6:867-878.

802 803

Young, I. R., S. Zieger, and A. V. Babanin. 2011. Global trends in wind speed and wave height. Science 332:451.

804 805 806 807 808 809 810 811 812 813 814 815 816 817 818 819
Zhu, L., Q. Chen, H. Wang, W. Capurso, L. Niemoczynski, K. Hu, and G. Snedden. 2020. Field Observations of Wind Waves in Upper Delaware Bay with Living Shorelines. Estuaries and Coasts 43:739-755. 
820 Table 1. Studies that have reported the percent of time a reef should be inundated for the optimal 821 recruitment, survival and/or growth of Crassostrea virginica.

State Inundation duration

\begin{tabular}{cc}
\hline North Carolina & $82-95 \%{ }^{1}$ \\
North Carolina & $60-80 \%{ }^{2}$ \\
North Carolina & $72-82 \%{ }^{3}$ \\
North Carolina to Florida & $52-84 \%{ }^{4}$ \\
Florida & $80-95 \%{ }^{5}$ \\
Louisiana & $52-94 \%{ }^{6}$ \\
\hline${ }^{1}$ Fodrie et al. (2014); ${ }^{2}$ Ridge et al. (2014); ${ }^{3}$ Ridge et al. \\
(2017); ${ }^{4}$ Byers et al. $(2015) ;{ }^{5}$ Solomon et al. $(2014) ;$ \\
${ }^{6}$ Marshall and La Peyre (2020)
\end{tabular}

822

823

824

825

826

827

828

829

830

831

832

833

834

835

836

837

838

839

840

841 
842 Table 2. Characteristics of oyster reef living shorelines and rock sills and natural oyster reefs.

843 Crest elevation where available is given in metres relative to NAVD88. Age is number of years

844 at time of study. The percent of time the structures are inundated (\% inundation duration) is

845 given when (a) measured during RBR deployment; (b) calculated based on USGS gauges for

846 deployment period; and (c) calculated based on USGS gauges from January 2017 - August 2019.

847 For more oyster reef living shorelines characteristics refer to Appendix 1: Table S1. *Note this

848 site is in Delaware. - data unavailable.

\begin{tabular}{|c|c|c|c|c|c|c|c|c|c|c|}
\hline \multirow[t]{2}{*}{$\begin{array}{c}\text { State/ } \\
\text { Reef }\end{array}$} & \multirow[t]{2}{*}{ Type } & \multirow[t]{2}{*}{$\begin{array}{l}\text { Age } \\
\text { (yrs) }\end{array}$} & \multirow[t]{2}{*}{$\begin{array}{c}\text { Length } \times \\
\text { Width (m) }\end{array}$} & \multirow[t]{2}{*}{$\begin{array}{c}\text { Height } \\
\text { (m) }\end{array}$} & \multirow[t]{2}{*}{$\begin{array}{c}\text { Crest } \\
\text { elevation }\end{array}$} & \multirow[t]{2}{*}{$\begin{array}{c}\text { Tidal } \\
\text { range (m) }\end{array}$} & \multicolumn{3}{|c|}{$\begin{array}{c}\% \text { inundation } \\
\text { duration }\end{array}$} & \multirow[t]{2}{*}{$\begin{array}{c}\text { \% oysters } \\
( \pm \mathrm{SE})\end{array}$} \\
\hline & & & & & & & (a) & (b) & (c) & \\
\hline NJ1 & Concrete & 2 & $6 \times 1$ & 0.65 & -0.48 & & 82.4 & 87.7 & 80.2 & $41.2 \pm 5.2$ \\
\hline $\mathrm{NJ} 2$ & Shell & 2 & $51 \times 6$ & 0.17 & -0.57 & 1.7 & 68.7 & 74.7 & 75.2 & $0.4 \pm 0.4$ \\
\hline NJ3* & Concrete & 4 & $2 \times 1$ & 0.53 & 0.01 & & 68.7 & 58.6 & 52.6 & $11.3 \pm 4.4$ \\
\hline VA1 & Concrete & 2 & $16 \times 0.6$ & 0.40 & 0.00 & & 67.6 & 53.4 & 50.9 & $6.2 \pm 1.7$ \\
\hline VA2 & Shell & 1 & $35 \times 0.9$ & 0.30 & 0.04 & 0.7 & 75.7 & 66.1 & 54.4 & 0 \\
\hline VA3 & Concrete & 1 & $28 \times 0.85$ & 0.30 & 0.01 & & 90.9 & 80.0 & 53.5 & 0 \\
\hline FL1 & Shell & 8 & $55 \times 5.25$ & 0.64 & - & & 38.1 & - & - & $2.4 \pm 1.6$ \\
\hline FL2 & Shell & 1 & $30 \times 6.67$ & 0.29 & 0.41 & 0.3 & 97.2 & 100 & 98 & $74.0 \pm 3.5$ \\
\hline FL3 & Shell & 2 & $20 \times 4$ & 0.27 & 0.38 & & 75.6 & 100 & 98 & $34.4 \pm 6.1$ \\
\hline AL1 & Shell & 9 & $65 \times 5$ & 0.60 & -0.37 & & 100 & 100 & 99.4 & - \\
\hline AL2 & Concrete & 8 & $125 \times 2.28$ & 0.23 & -0.24 & 0.4 & 100 & 100 & 98.3 & - \\
\hline AL3 & Shell & 8 & $125 \times 2.64$ & 0.31 & 0.17 & & 92.9 & 66.7 & 50.4 & - \\
\hline LA1 & Concrete & 1.5 & $130 \times 2.7$ & 1.40 & 0.84 & & 0 & 0 & 1.2 & - \\
\hline LA2 & Concrete & 1.5 & $178 \times 5.5$ & 1.40 & 0.66 & 0.4 & 0 & 0 & 4.8 & - \\
\hline LA3 & Concrete & 7 & $75 \times 3$ & 1.10 & -0.06 & & 63.0 & 81.0 & 84.4 & - \\
\hline VA1 & Rock sill & 2 & $29.4 \times 2.4$ & 0.69 & 0.46 & & 30.7 & 8.9 & 9.2 & $1.2 \pm 0.4$ \\
\hline VA2 & Rock sill & 7 & $41.3 \times 1.9$ & 0.84 & 0.40 & 0.7 & 35.7 & 16.3 & 13.9 & $14.4 \pm 4.5$ \\
\hline VA3 & Rock sill & 1 & $51.4 \times 3.6$ & 1.02 & 1.03 & & 8.9 & 0 & 0.02 & 0 \\
\hline FL1 & Natural & - & $47 \times 7.8$ & 0.64 & - & & 38.1 & - & - & $0.4 \pm 0.4$ \\
\hline
\end{tabular}




\begin{tabular}{|c|c|c|c|c|c|c|c|c|c|c|}
\hline FL2 & Natural & - & $35 \times 5.9$ & 0.49 & - & 0.3 & 58.3 & - & - & $4.0 \pm 2.7$ \\
\hline FL3 & Natural & - & $35 \times 3.1$ & 0.33 & - & & 64.4 & - & - & $2.4 \pm 1.7$ \\
\hline
\end{tabular}

849

850

851

852

853

854

855

856

857

858

859

860

861

862

863

864

865

866

867

868

869

870

871

872

873

874 
875 Figure 1. A map of the five study areas. In each study area (red dots) there were three oyster 876 reef-control pairs, a schematic example of the wave logger (RBR) set-up for one pair is shown.

877 The circles (oyster reef treatment) and triangles (control treatment; no reef) indicate wave sensor 878 deployment (not to scale). For a detailed map of each area see Appendix 1: Fig. S1.

879 Figure 2. (a) Significant wave heights (m) at the offshore wave logger (RBR); and (b) the 880 average depth $(\mathrm{m})$ recorded during each burst at 15 oyster reef living shorelines across five 881 locations (New Jersey/Delaware, Virginia, Florida, Alabama, Louisiana from left to right). The 882 red lines in (b) indicate the height of the reef ( $\mathrm{m}$; matching scale on y-axis).

883 Figure 3. Comparisons of measured (y-axis) and predicted (x-axis) significant wave height (m)

884 for (a) control $\left(\mathrm{R}^{2}=0.97\right)$; (b) oyster reef living shorelines with an inundation duration above 50\% $885\left(\mathrm{R}^{2}=0.97\right)$ and below $50 \%\left(\mathrm{R}^{2}=0.78\right)$; (c) reefs that have an inundation duration of more than $88650 \%$ and widths of less than $1 \mathrm{~m}\left(\mathrm{R}^{2}=0.97\right), 2-4 \mathrm{~m}(\mathrm{R} 2=0.97)$ and $5-7 \mathrm{~m}(\mathrm{R} 2=0.96)$; and $(\mathrm{d})$ reefs 887 constructed of concrete $\left(\mathrm{R}^{2}=0.88\right)$ and shell $\left(\mathrm{R}^{2}=0.96\right)$. Values below the dotted line indicate a 888 decrease in wave height. The decrease in wave height is given as a percentage on the graphs. The 889 shaded area is the $95 \%$ confidence interval.

890 Figure 4. Correlation between the wave transmission coefficient $(\mathrm{Kt})$ and freeboard $(\mathrm{m})$ for reefs 891 that have an inundation duration of less or greater than $50 \%$. A wave transmission value of less 892 than one indicates a reduction in wave height. A positive or negative freeboard value indicates 893 the reef is emerged or submerged, respectively. The shaded area is the $95 \%$ confidence interval. 894 Figure 5. Comparisons of measured (y-axis) and predicted (x-axis) significant wave height (m) 895 for $(\mathrm{a})$ control $\left(\mathrm{R}^{2}=0.99\right)$, rock sill $\left(\mathrm{R}^{2}=0.94\right)$, and oyster reef living shoreline $\left(\mathrm{R}^{2}=0.98\right)$ in 896 Virginia; (b) control $\left(\mathrm{R}^{2}=0.84\right)$, natural oyster reef $\left(\mathrm{R}^{2}=0.15\right)$, and oyster reef living shoreline 
$897\left(\mathrm{R}^{2}=0.31\right)$ in Florida. Values below the dotted line indicate a decrease in wave height. The 898 shaded area is the $95 \%$ confidence interval.

899

900

901

902

903

904

905

906

907

908

909

910

911

912

913

914

915

916

917

918

919 
Figure 1

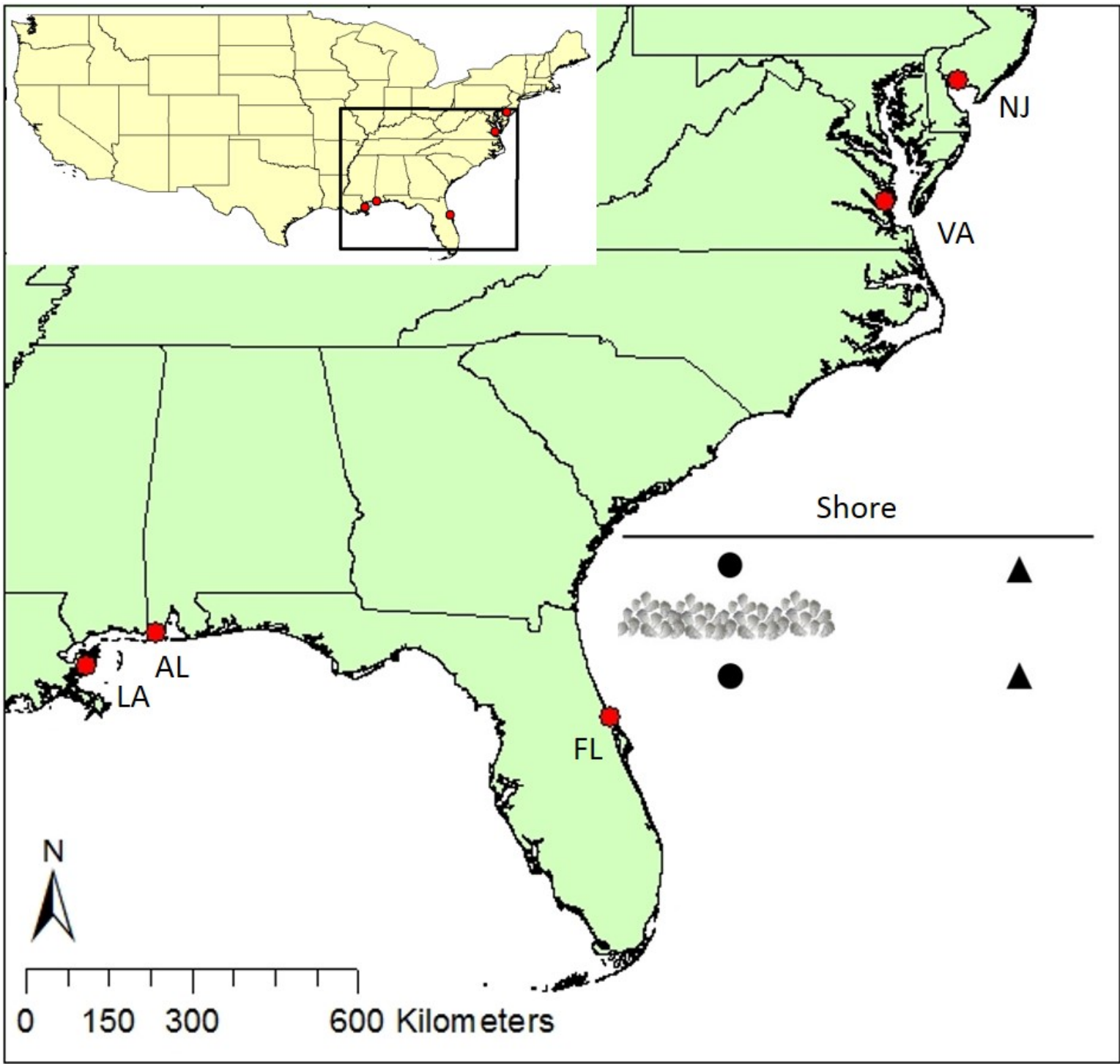

922

923

924

925

926

927

928 
Figure 2
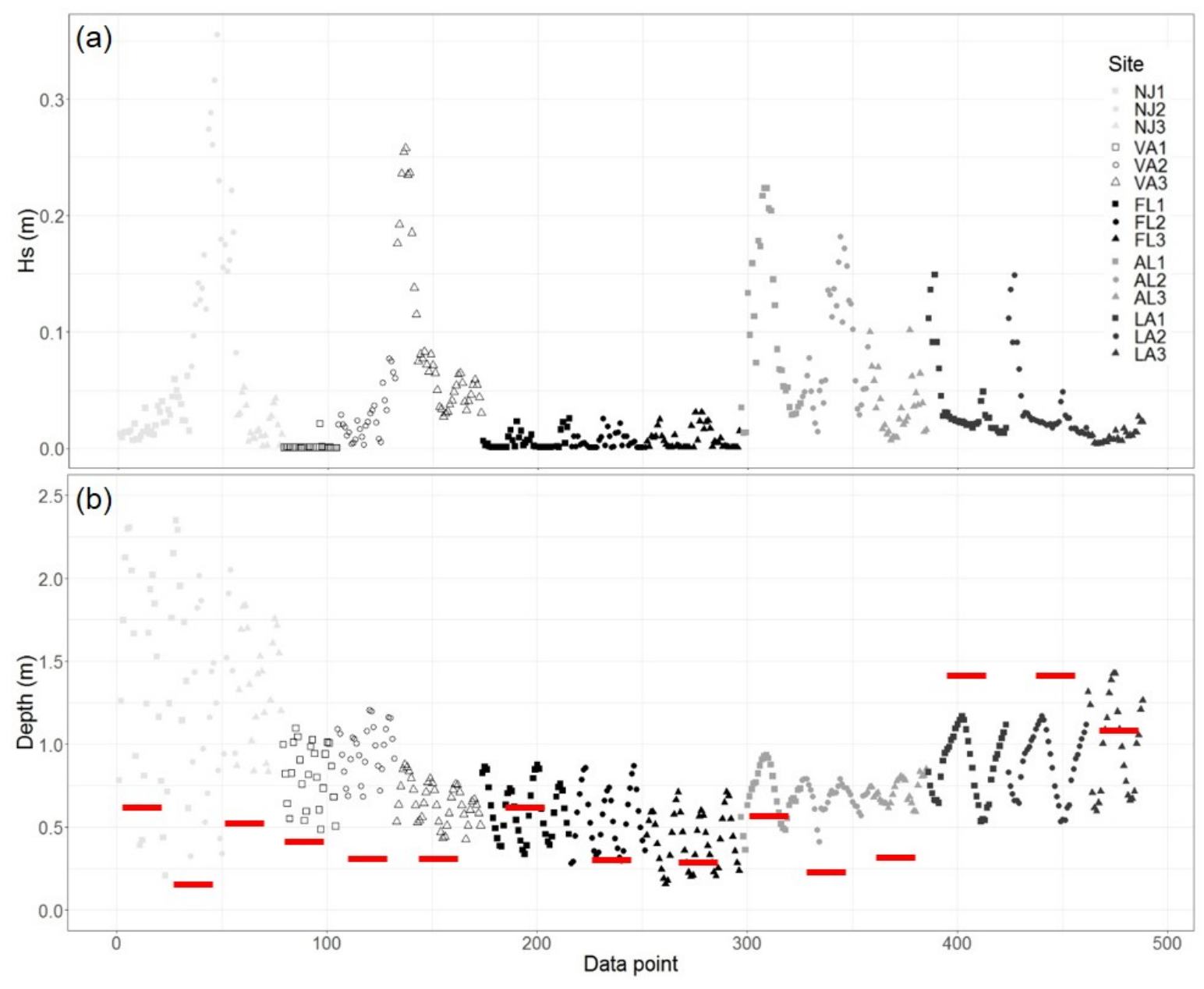
Figure 3
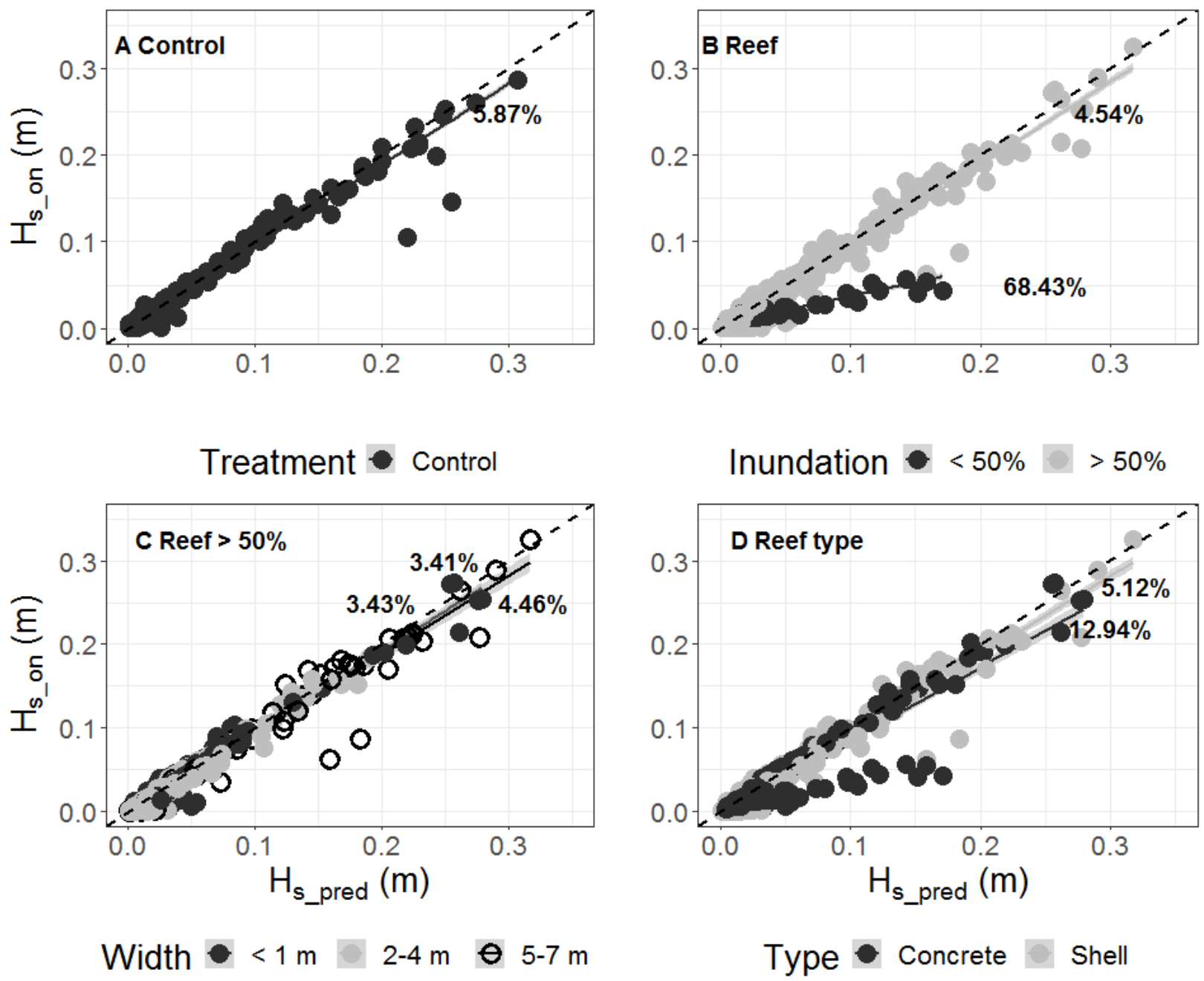
Figure 4

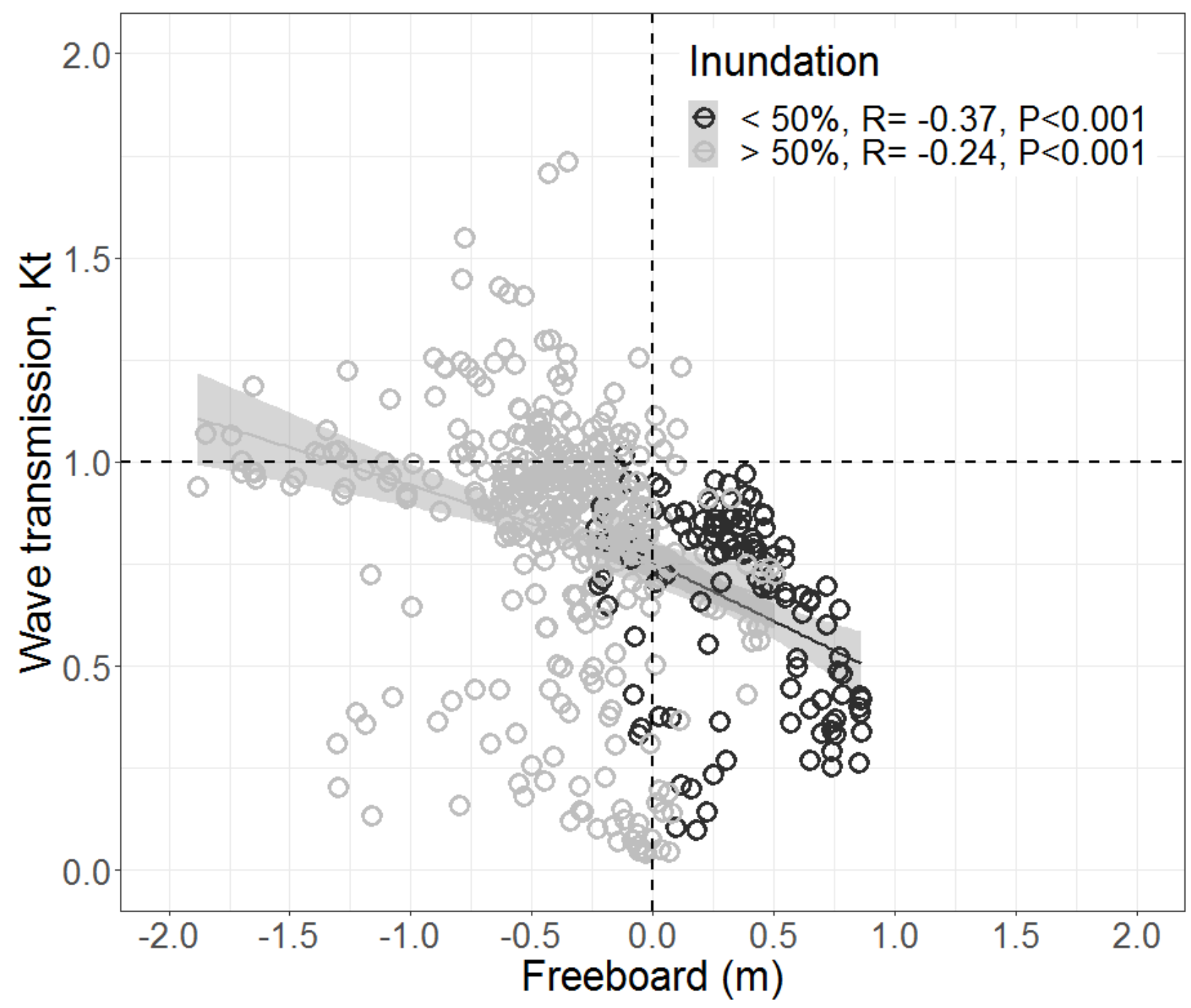

951

952

953

954

955

956

957

958

959 
Figure 5
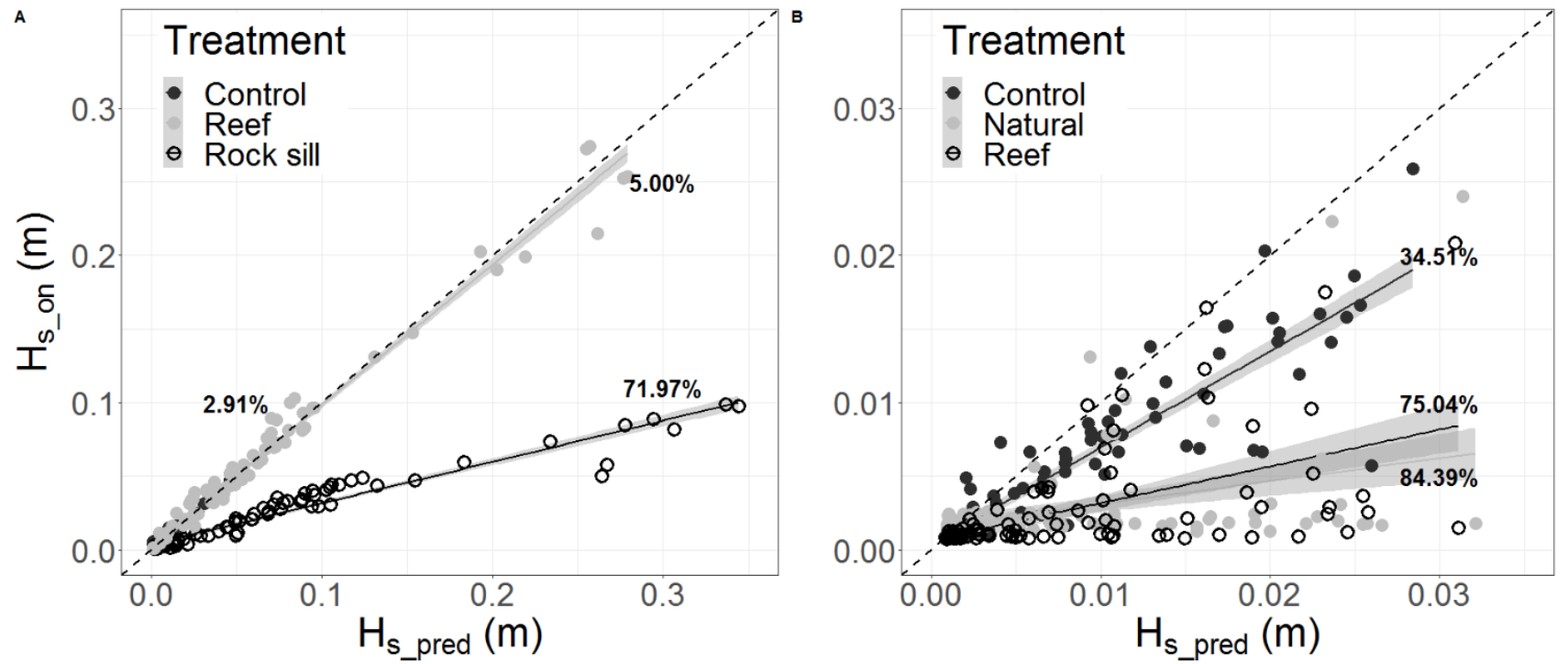

961

962

963 